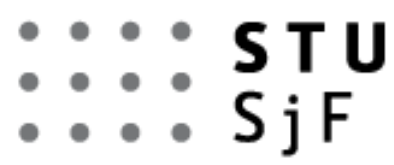

DE GRUYTER OPEN

\section{Journal of MECHANICAL ENGINEERING \\ - Strojnícky časopis}

VOLUME 66, NO 1, 2016

pp. $37-46$

DOI:10.1515/scjme-2016-0009

\title{
INTERNAL COMBUSTION ENGINE POWERED BY SYNTHESIS GAS FROM PYROLYSED PLASTICS
}

\author{
CHRÍBIK Andrej ${ }^{1}$, POLÓNI Marián ${ }^{1}$, LACH Ján ${ }^{1}$ \\ JANČOŠEK L'ubomír ${ }^{2}$, KUNC Peter ${ }^{2}$, ZBRANEK Josef ${ }^{2}$ \\ ${ }^{1}$ Slovak University of Technology in Bratislava, Faculty of Mechanical Engineering, Institute of \\ Transport Technology and Engineering Design, Námestie slobody 17, 81231 Bratislava, Slovakia, \\ e-mail:andrej.chribik@stuba.sk,marian.poloni@stuba.sk, jan.lach@stuba.sk \\ ${ }^{2}$ Enmon, a. s., Robotnicka 14/9856, 03601 Martin, Slovakia, \\ e-mail:l.jancosek@engul.sk,p.kunc@engul.sk,j.zbranek@engul.sk
}

\begin{abstract}
The article discusses the application of synthesis gas from pyrolysis of plastics in petrol engine. The appropriate experimental measurements were performed on a combustion engine LGW 702 designated for micro-cogeneration unit. The power parameters, economic parameters in term of brake specific fuel consumption, and internal parameters of the engine were compared to the engine running on the reference fuel natural gas and synthesis gas. Burning synthesis gas leads to decreased performance by about $5 \%$ and to increased mass hourly consumption by $120 \%$. In terms of burning, synthesis gas has similar properties as natural gas. Compared with [5] a more detailed study has been prepared on the effects of angle of spark advance on the engine torque, giving more detailed assessment of engine cycle variability and considering specification of start and end of combustion in the logarithm $\mathrm{p}-\mathrm{V}$ diagram.
\end{abstract}

KEYWORDS: natural gas, synthesis gas, spark ignition engine, cogeneration unit, cycle variability

\section{Introduction}

Municipal waste with its quantity and quality represents a significant environmental burden. Therefore, solutions are being developed on possible most effective utilisation of the hidden energy potential of that waste. One possibility is separation of plastics from waste and subsequent conversion of this waste via pyrolytic process to gaseous fuel, which is a carrier of energy. This fuel can then be effectively utilised in the cogeneration unit. One such workplace for separation of communal waste and subsequent processing is located in Čierny Brod-Zúgov with installed separators of municipal waste. The separated plastics will be processed by pyrolysis and thus converted into a gaseous fuel. An analysis of the primary fuel from the pyrolysis process consisted of more than twenty components, which number would mean a rather complicated experimental verification on the engine. Therefore, two gas compositions were selected, which are a mix of five components each and labelled as SGE0 and SGE1. Our department has experimentally verified the gas labelled SGE1 that has the following composition: methane $\mathrm{CH}_{4} 10 \%$ vol., ethane $\mathrm{C}_{2} \mathrm{H}_{6} 31 \%$ vol., carbon monoxide $\mathrm{CO} 7 \%$ vol., hydrogen $\mathrm{H}_{2} 12 \%$ vol., carbon dioxide, $\mathrm{CO}_{2} 40 \%$ vol. This gas mix best resembles the properties of real (SGE0) pyrolysed plastics gas composition. To complete the info, the SGE0 gas composition was as follows: methane $\mathrm{CH}_{4} 6 \%$ vol., n-butane $\mathrm{C}_{4} \mathrm{H}_{10} 14 \%$ vol., propylene $\mathrm{C}_{3} \mathrm{H}_{6} 6$ vol. $\%$, hydrogen $\mathrm{H}_{2} 8 \%$ vol., nitrogen $\mathrm{N}_{2} 66 \%$ vol.. The following table shows basic physical and chemical properties of the referential fuel entering the comparison (natural gas 97\% vol. methane), and the two gas fuel compositions, out of which the gas labelled SGE1 
was experimentally referenced. Comparing natural gas with synthesis gas SGE1, the lower heating value (LHV) is lower by $62 \%$ (by weight), or lower by $30 \%$ (by volume). The volumetric heating value of the stoichiometric mixture of synthesis gas SGE1 and air is lower by $6.6 \%$ than is the volumetric heating value of the stoichiometric mixture of natural gas and air. For this reason, we can expect somewhat lower performance parameters of the engine when operating on synthesis gas [1], [2], [8]. For prediction of performance parameters by modelling we often use the software Lotus Engine Simulation. Example is given in [7].

Tab. 1 Basic physical-chemical properties of fuel mixtures

\begin{tabular}{|c|c|c|c|c|}
\hline Parameter & Unit & Natural Gas & SGE0 & SGE1 \\
\hline LHV & {$\left[\mathrm{kJ} . \mathrm{kg}^{-1}\right]$} & 48796 & 18352 & 18603 \\
\hline LHV & {$\left[\mathrm{kJ} \cdot \mathrm{m}^{-3}\right]$} & 33838 & 23096 & 23767 \\
\hline Density & {$\left[\mathrm{kg} \cdot \mathrm{m}^{-3}\right]$} & 0.693 & 1.259 & 1.278 \\
\hline Molar mass & {$\left[\mathrm{g} \cdot \mathrm{mol}^{-1}\right]$} & 16.69 & 30.29 & 30.74 \\
\hline A/F ratio & {$\left[\mathrm{kg} \cdot \mathrm{kg}^{-1}\right]$} & 16.98 & 6.17 & 6.57 \\
\hline fuel/air ratio & {$[\% \mathrm{vol}]$.} & $9.3 / 90.7$ & $13.4 / 86.6$ & $12.3 / 87.7$ \\
\hline fuel/air ratio & {$[\% \mathrm{~m}]$.} & $5.6 / 94.4$ & $14.0 / 86.0$ & $13.2 / 86.8$ \\
\hline LHV mixture & {$\left[\mathrm{kJ} \cdot \mathrm{kg}^{-1}\right]$} & 2713 & 2569 & 2456 \\
\hline LHV mixture & {$\left[\mathrm{kJ} \cdot \mathrm{m}^{-3}\right]$} & 3130 & 3095 & 2923 \\
\hline
\end{tabular}

The investigated gas fuel SGE1 was delivered as a compressed gas in a pressure container. In applications the synthesis gas, entering the engine, is pure, without any mechanical impurities and with negligible amount of tar. Because of the cost of acquisition of that fuel the experimental measurements were performed on a small combustion engine LGW 702 Lombardini suitable for micro-cogeneration unit [3].

The basic parameters of the combustion engine Lombardini LGW 702 are given in Table 2.

The producer of the engine has performed adaptations as follows:

- replacement of the original head of the diesel-engine version of the combustion engine for the head with openings for installing spark plugs,

- decrease of compression ratio to 12.5:1, realised by replacement of the original pistons for pistons with a cavity in the bottom of the pistons of the requested volume and shape,

- supply of original intake manifold with common container and electronically controlled throttle.

Tab. 2 Basic parameters of combustion engine Lombardini LGW 702

\begin{tabular}{|lc|c|}
\hline \multicolumn{2}{|l|}{ Crankshaft throw angle $\left[{ }^{\circ}\right]$} & 360 \\
\hline Swept volume & {$\left[\mathrm{cm}^{3}\right]$} & 686 \\
\hline Bore/ Stroke $\quad[\mathrm{mm}]$ & $75 / 77,6$ \\
\hline Compression ratio $\quad[-]$ & $12.5: 1$ \\
\hline Valve gear/ Drive & OHC/Belt drive system \\
\hline Fuel & Natural gas (and alternative gasses) \\
\hline Lubrication system & $\begin{array}{r}\text { Pressure circuit, full-flow filtration, } \\
\text { oil filling 1.6 1 }\end{array}$ \\
\hline
\end{tabular}




\section{Experimental Measurements and Results}

\subsection{Combustion engine Lombardini LGW 702}

The experimental measurements were performed on Lombardini combustion engine LGW 702. It is a two-cylinder water-cooled spark ignition engine with displacement of $686 \mathrm{~cm}^{3}$ and compression ratio of 12.5:1. The mixture was prepared using a mixer with a diffuser. The richness of the mixture was set by means of an electronic control unit VOILA. The combustion engine comprised a programmable control unit, through which it was possible to manually set the spark advance angle The primary objective was to determine the optimum angle of spark advance for the anticipated operating speed of the cogeneration unit (1500 $\mathrm{min}^{-}$ $\left.{ }^{1}\right)$ and with this optimum angle to measure all major engine characteristics. In addition to the performance and economic parameters, an analysis of the internal engine parameters was performed as well. The course of pressures in the combustion space was recorded with a piezoelectric pressure sensor from the company Kistler that was integrated in the spark plug. To correct the dynamic pressure a piezo-resistive pressure sensor was used and it was placed in the intake manifold. Both signals from the pressures and the signal from the crankshaft position were processed by the program created in Matlab.

\subsection{Measurement Results}

The following subsection describes the core results of the measured impact of synthesis gas on the parameters of the internal combustion engine as compared to the influence of natural gas. The following figure (Fig. 1) shows the courses of torque and effective power as depending on the engine speed at burning natural gas and synthesis gas. The comparison has shown that in the case of combusting synthesis gas, the drop in power, or torque, is by about $5 \%$. The maximum torque ( $42.9 \mathrm{~N} . \mathrm{m})$ is achieved at the speed of $1600 \mathrm{~min}^{-1}$. The decrease of the power parameters relates to the decrease of calorific value of the mixture, as there is a high percentage of inert gas in the synthesis gas.

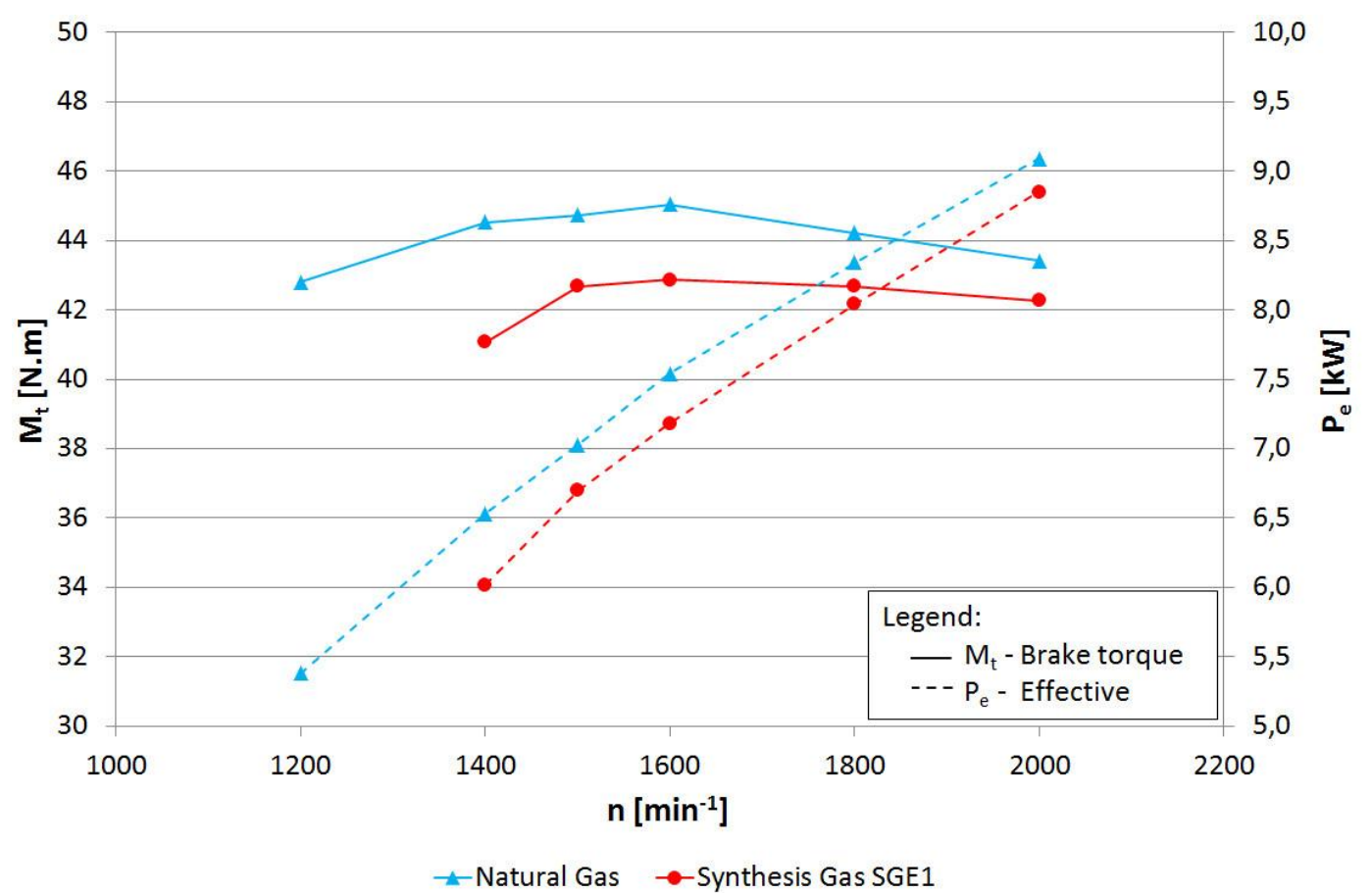

Fig. 1 Courses of torque $\left(\mathrm{M}_{\mathrm{t}}\right)$ and effective power $\left(\mathrm{P}_{\mathrm{e}}\right)$, as depending on the engine speed during combustion of natural gas or synthesis gas SGE1

(Conditions: spark advance $\varphi_{\mathrm{ign}}=25^{\circ} \mathrm{CA} \mathrm{BTDC}$, load $\alpha_{\text {throttle }}=100 \%$, air excess ratio $\lambda=1$ )

Volume 66, No. 1, (2016) 
Fig. 2 shows the hourly fuel consumption and brake specific fuel consumption, depending on the engine speed at burning natural and synthesis gas. The hourly fuel consumption rose during combustion of synthesis gas on average by approximately $120 \%$ within the entire speed range as compared to natural gas consumption. For the examined speed of $1500 \mathrm{~min}^{-1}$ the hourly consumption of synthesis gas is higher by $2.1 \mathrm{~kg} \cdot \mathrm{h}^{-1}$ compared to the consumption of natural gas, which can be explained by a higher mass amount of synthesis gas in the stoichiometric mixture with air. Comparing the brake effective fuel consumption, the lowest value (245 g. $\mathrm{kW}^{-1} \cdot \mathrm{h}^{-1}$ ) has been achieved while running on natural gas. When operating on synthesis gas the consumption has achieved the value $555 \mathrm{~g} \cdot \mathrm{kW}^{-1} \cdot \mathrm{h}^{-1}$. The mean effective pressure at the operating speed $\left(1500 \mathrm{~min}^{-1}\right)$ for the natural gas is $820 \mathrm{kPa}$, and for the synthesis gas the value is $781 \mathrm{kPa}$.

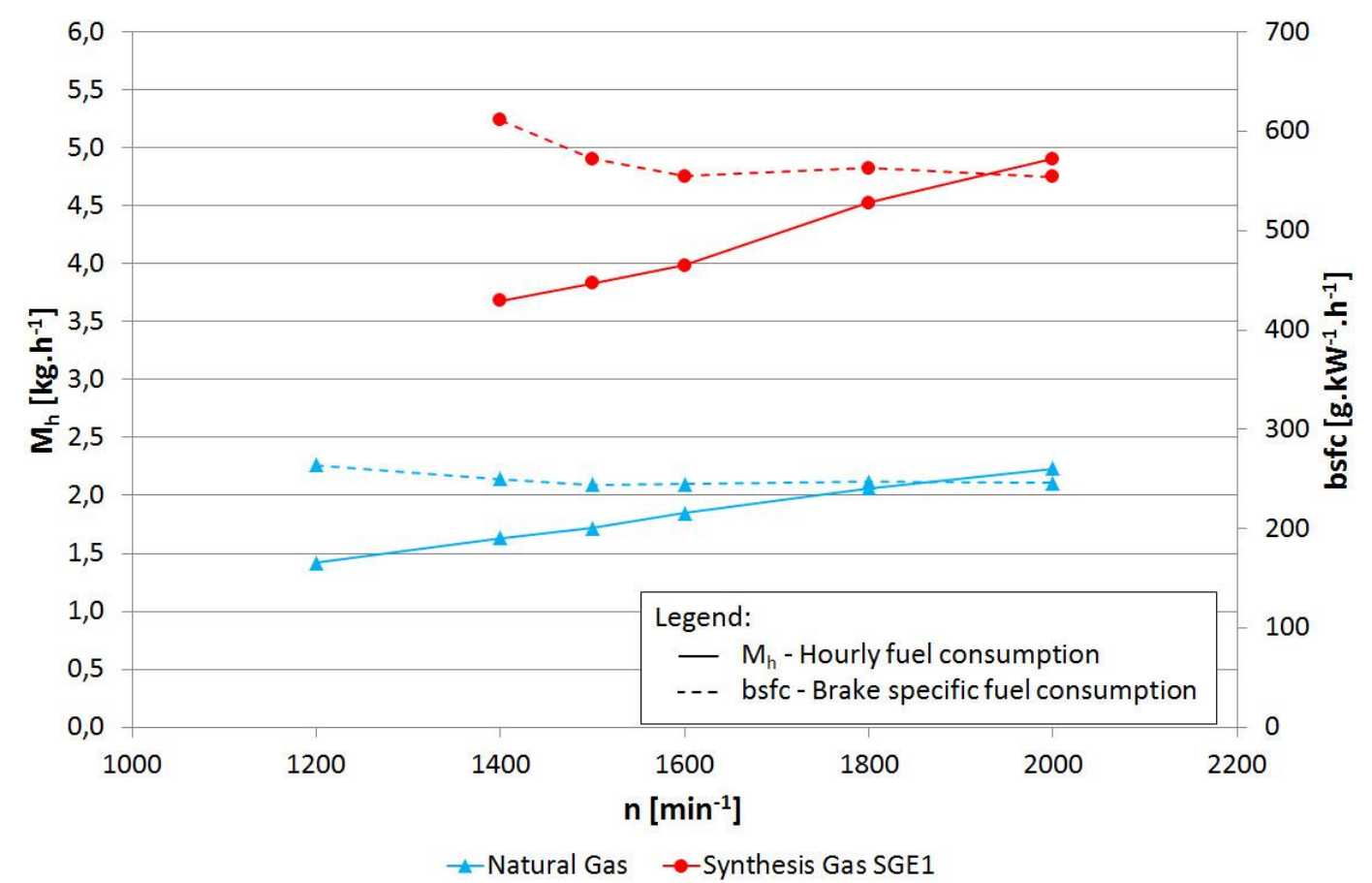

Fig. 2 Courses of hourly fuel consumption $\left(\mathrm{M}_{\mathrm{h}}\right)$ and brake specific fuel consumption (BSFC) as dependent on the engine speed under combustion of natural and synthesis gas (Conditions: spark advance $\varphi_{\text {ign }}=25^{\circ} \mathrm{CA}$ BTDC, full load, stoichiometric mixture)

Fig. 3 shows dependence of engine torque during on the change of the angle of advance on combustion of natural gas, or synthesis gas, at the speed of $1500 \mathrm{~min}^{-1}$. As can be seen from the chart, the optimum value of the angle of advance is at $25^{\circ} \mathrm{CA}$ BTDC, when a maximum torque of 44.6 N.m (natural gas) was obtained, or at 42.7 N.m (syngas SGE1). The characters of the torque curves are the same for both fuels. 


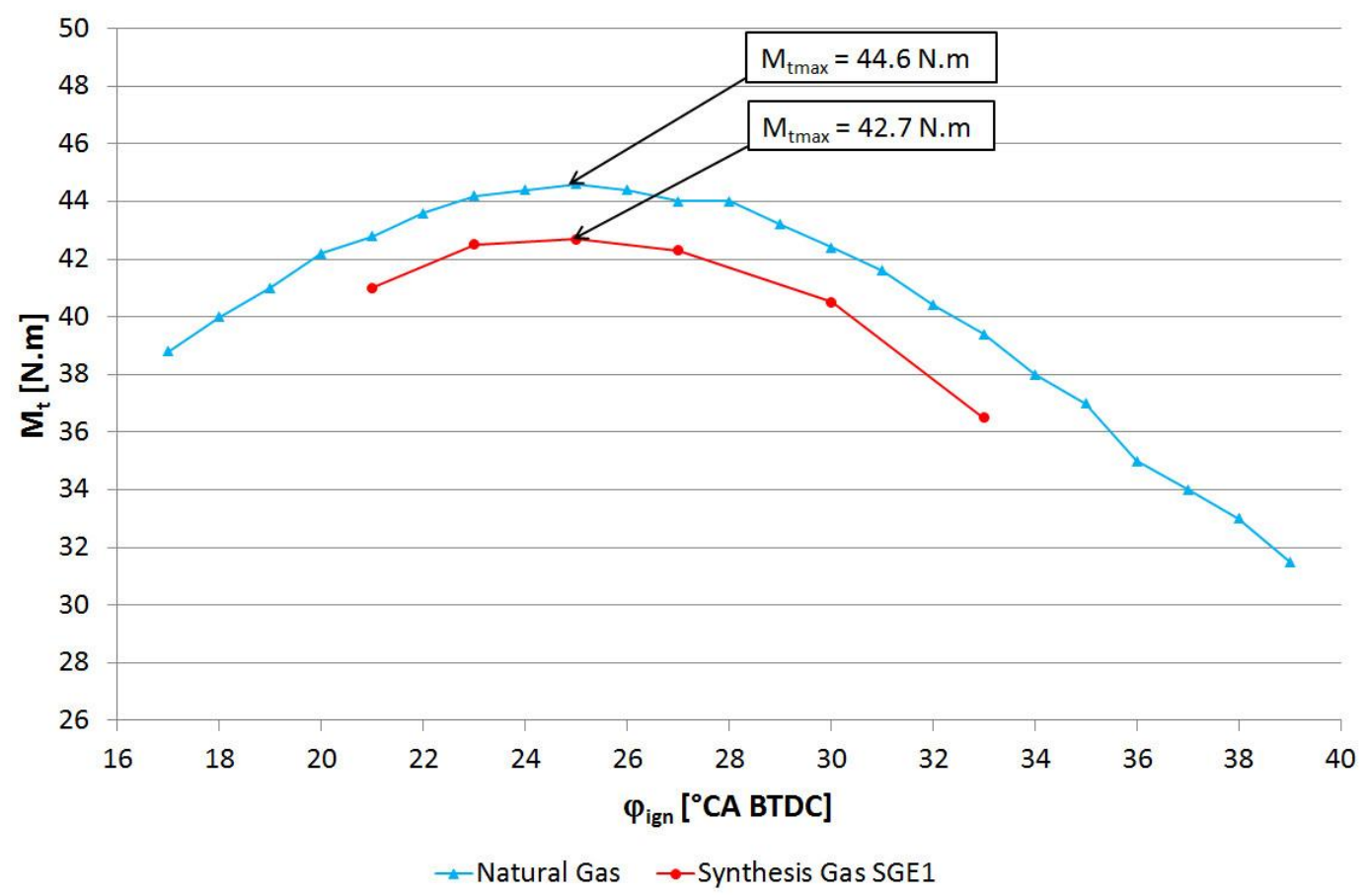

Fig. 3 Courses of engine torque $\left(\mathrm{M}_{\mathrm{t}}\right)$ as dependent on spark advance $\left(\varphi_{\text {ign }}\right)$ in the case of natural and synthesis gas SGE1

(Conditions: speed $\mathrm{n}=1500 \mathrm{~min}^{-1}$, full load, stoichiometric mixture)

Simultaneously with measuring integral parameters an analysis of the course of pressure in the combustion chamber of the engine was performed together with the analysis of the effect of synthesis gas burning on the parameters directly relative to the actual course of burning.

The following figure (Fig. 4) shows the courses of pressures for combustion of natural and synthesis gas. It can be seen from the courses that the maximum pressure in combustion of natural gas is $6.045 \mathrm{MPa}$ in the position $371.7^{\circ} \mathrm{CA}$. When burning synthesis gas a lower value 5.820 $\mathrm{MPa}$ has been achieved in the position $372.4^{\circ} \mathrm{CA}$. Thus, it is presumed that the wear of piston group will be the same.

The pressure development data that were obtained can indicate the characteristics of the operation of the internal combustion engine (variability of cycles), which is most often expressed by the so-called coefficient of variation (COV). The coefficient of variation is calculated as follows:

$$
\operatorname{COV}=\frac{\sqrt{\frac{1}{n-1} \sum_{i=1}^{n} x_{i}-\bar{x}}}{\bar{x}} \cdot 100 \quad[\%]
$$

The coefficient of variation from 195 consecutive cycles for the value of the maximum pressure is $10.9 \%$ for natural gas, and $6.6 \%$ for synthesis gas. Considering pressure rise increase (pressure increase per unit of crank angle rotation) it is more advantageous to burn natural gas $\left(0.199 \mathrm{MPa} / 1^{\circ} \mathrm{CA}\right)$ than synthesis gas $\left(0.227 \mathrm{MPa} / 1^{\circ} \mathrm{CA}\right)$, in view of the overall engine life. The ignition delay pertaining to the same operating conditions takes less time in combustion of natural gas $\left(1.465 \mathrm{~ms}\right.$ or $13.2^{\circ} \mathrm{CA}$ for the speed of $\left.1500 \mathrm{~min}^{-1}\right)$ than in combustion of synthesis gas (1.564 $\mathrm{ms}$ or $14.1^{\circ} \mathrm{CA}$ for the same speed). 


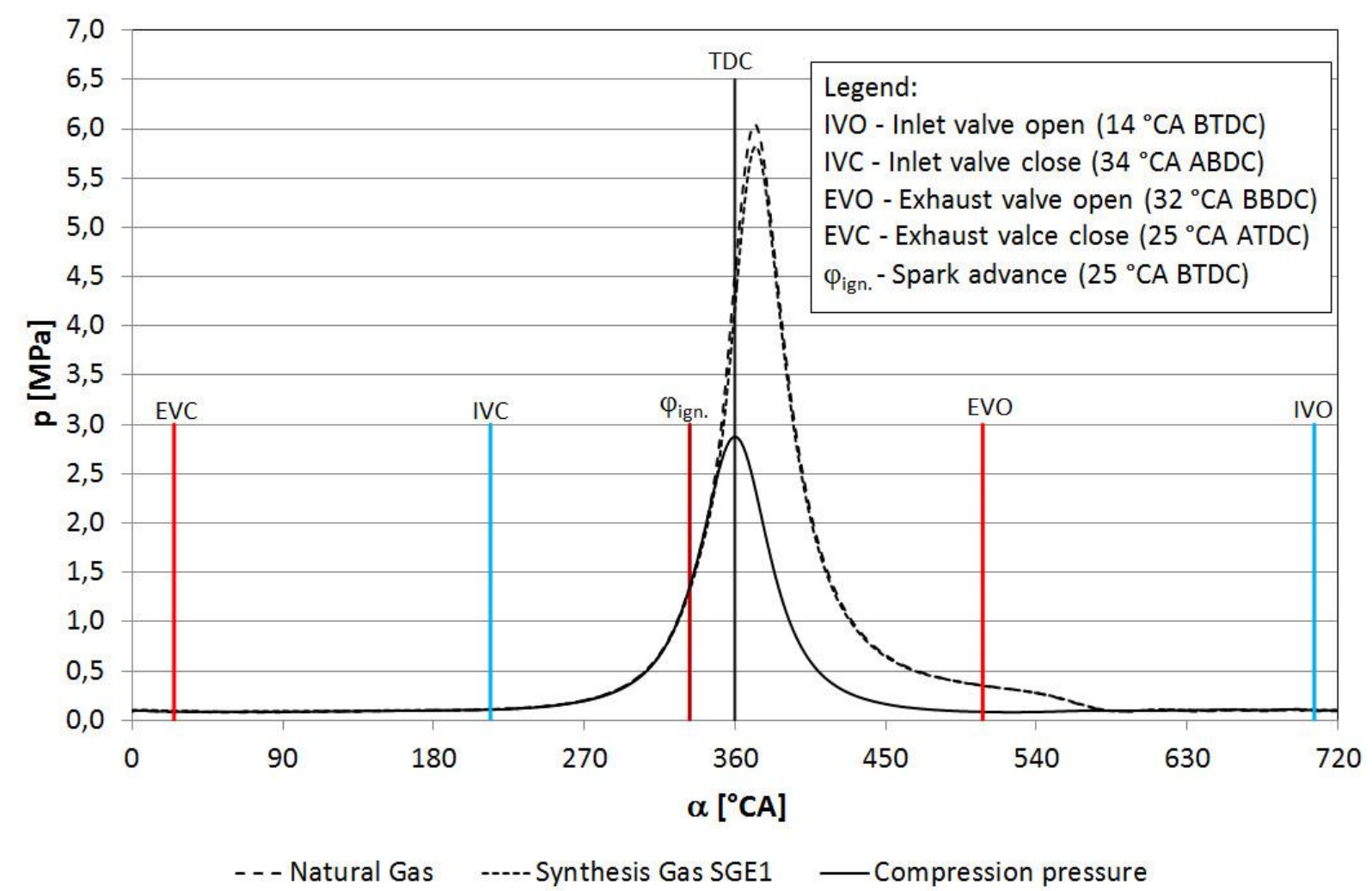

Fig. 4 Comparison of average pressure courses in the combustion chamber of the engine during combustion of natural gas or synthesis gas

(Conditions: spark advance $\varphi_{\text {ign }}=25^{\circ} \mathrm{CA} \mathrm{BTDC}$, full load, air excess ratio $\lambda=1$ )

Fig. 5 depicts the above-mentioned values of maximum pressure for 190 successive cycles, combusting synthesis gas, with an indication of the average of the maximum pressure.

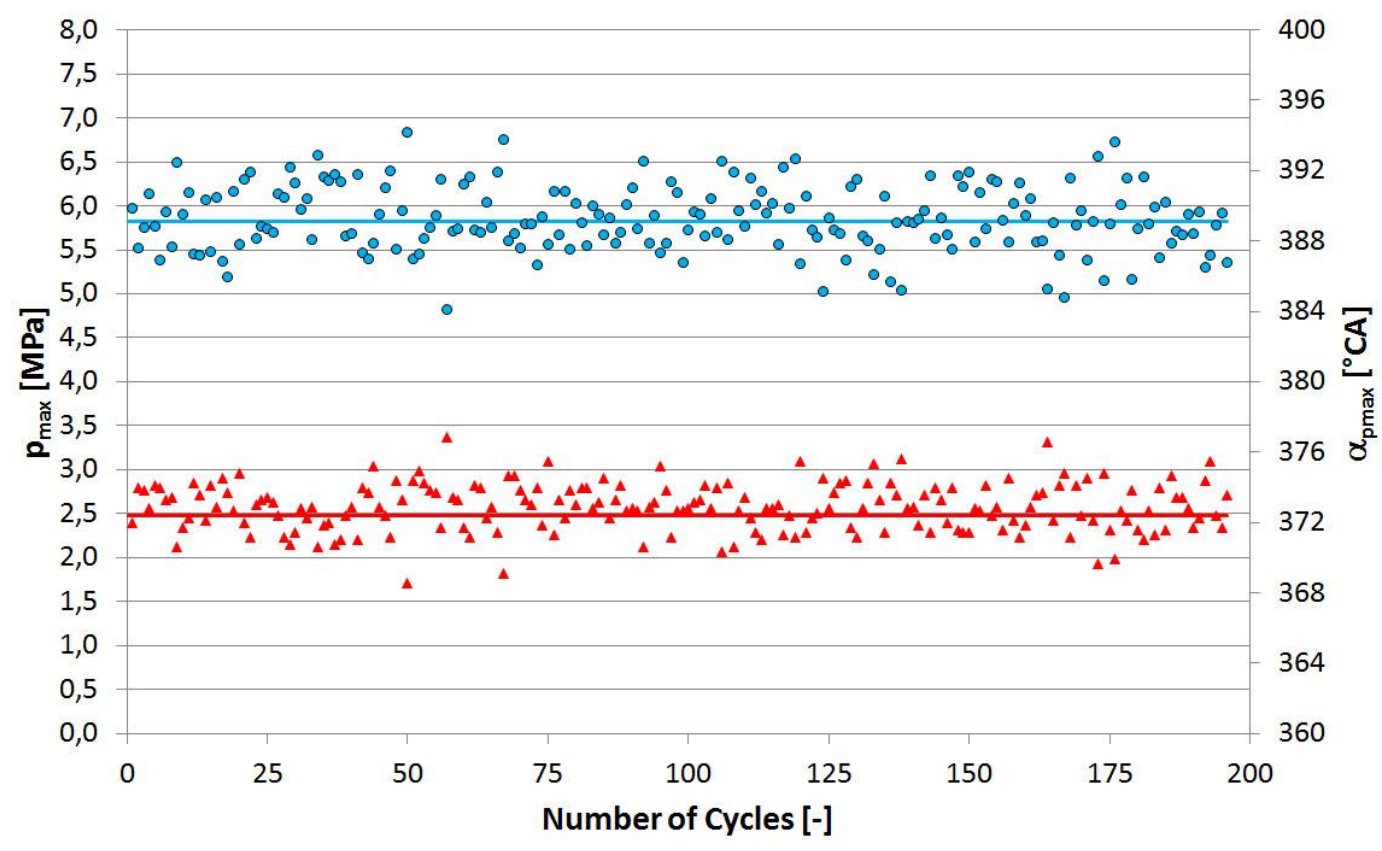

- max. pressure $\triangle$ possition of max. pressure

Fig. 5 The values of maximum pressure $\left(\mathrm{p}_{\max }\right)$, and positioning of maximum cylinder pressure $\left(\alpha_{\text {pmax }}\right)$ for particular successive cycles combusting synthesis gas SGE1

(Conditions: spark advance $\varphi_{\text {ign }}=25{ }^{\circ} \mathrm{CA}$ BTDC, full load, air excess ratio $\lambda=1$ ) 
The following figure (Fig 6) shows the logarithmic p - V diagram, with the help of which we determine the beginning and end of combustion. The polytrophic lines were constructed by the method of least squares. The deflection of the pressure curve from the polytrophic straight line in logarithmic coordinates determines the beginning of burning of the mixture (SOC). The value of the average polytrophic coefficient at compression is 1.33 , and at expansion 1.28. The decline of the coefficient relates with changes in specific heat capacity of the combustion products and partially with blowing through the piston rings into the crankcase space [6]. The end of combustion (EOC) was determined in a similar way as the start of combustion of the mixture.

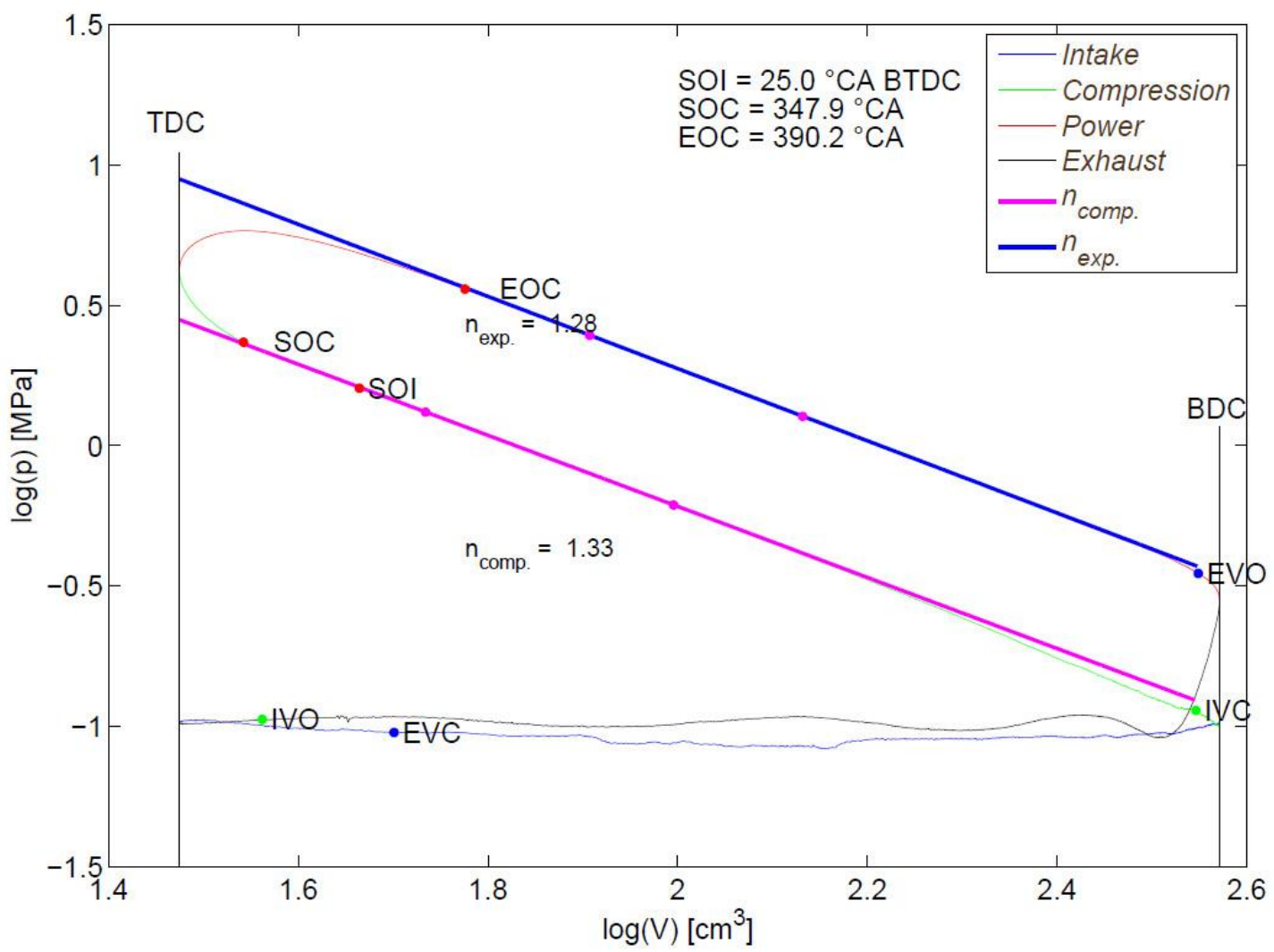

Fig. 6 Logarithmic p - V diagram of the pressure course related to the volume of the cylinder operating on synthesis gas SGE1

(Conditions: $\varphi_{\text {ign }}=25{ }^{\circ} \mathrm{CA} \mathrm{BTDC}$, full load, air excess ratio $\lambda=1$, speed $\mathrm{n}=1500 \mathrm{~min}^{-1}$ )

The figure (Fig. 7) shows the dependencies of the mass fraction burned (MFB) of the fuel on the crankshaft angle $\alpha$ for 195 consecutive cycles, as well as the average cycle value for natural and synthesis gas. The analysis leads us to the conclusion that combustion of synthesis gas leads to more stable combustion, which is also documented by a dispersion of individual curve courses for MFB. In the early stage the burning takes place faster for combustion of synthesis gas, when the angle at which the burnt fuel is $5 \%$ is $352.6^{\circ} \mathrm{CA}$ in the synthesis gas as compared to the natural gas $\left(354.5^{\circ} \mathrm{CA}\right)$. When $10 \%$ of fuel is burnt $(\mathrm{MFB}=0.1)$, the value of angle for the synthesis gas is $355.4^{\circ} \mathrm{CA}$. For the natural gas the position of the crankshaft has the value of $357.5^{\circ} \mathrm{CA}$. If higher values of MFB are present, the burning is faster in natural gas than in synthesis gas, which is reflected in closer agreement between angle positions of the crankshaft angle, when $50 \%$ of fuel is burnt. The average value of the position of the crankshaft, when MFB is 0.5 (50\% of fuel is burnt), is $366.2^{\circ} \mathrm{CA}$ for natural gas and for the synthesis gas this value is $366.5^{\circ} \mathrm{CA}$. When burning synthesis gas, the subsequent combustion takes place much faster than when burning natural gas, which can be expressed in 
numerically via the angle when $90 \%$ of fuel is burned (MFB $=0.9$ ). For natural gas, this value is $381.6^{\circ} \mathrm{CA}$ and for the synthesis gas the value is $377.7^{\circ} \mathrm{CA}$. A statistical analysis of coefficients of variation for particular periods, when successively $5 \%, 10 \%, 50 \%$ and $90 \%$ of fuel was burnt, indicates that combustion of the synthesis gas leads to reduced coefficients. The greatest difference between the coefficients of variation (COV [4]) is in burning $5 \%$ of fuel, when the COV value for synthesis gas is $0.385 \%$ and for the natural gas is $0.744 \%$. Generally (both for natural and synthesis gases) with rising MFB, the coefficient of variation of the crankshaft angle also increases. The highest value is reached when burning at $90 \%$ fuel $(\mathrm{MFB}=0.9)$, when the coefficient of variation of the angle for natural gas has the value 0.994 $\%$ and reaches the value $0.327 \%$ for the synthesis gas.
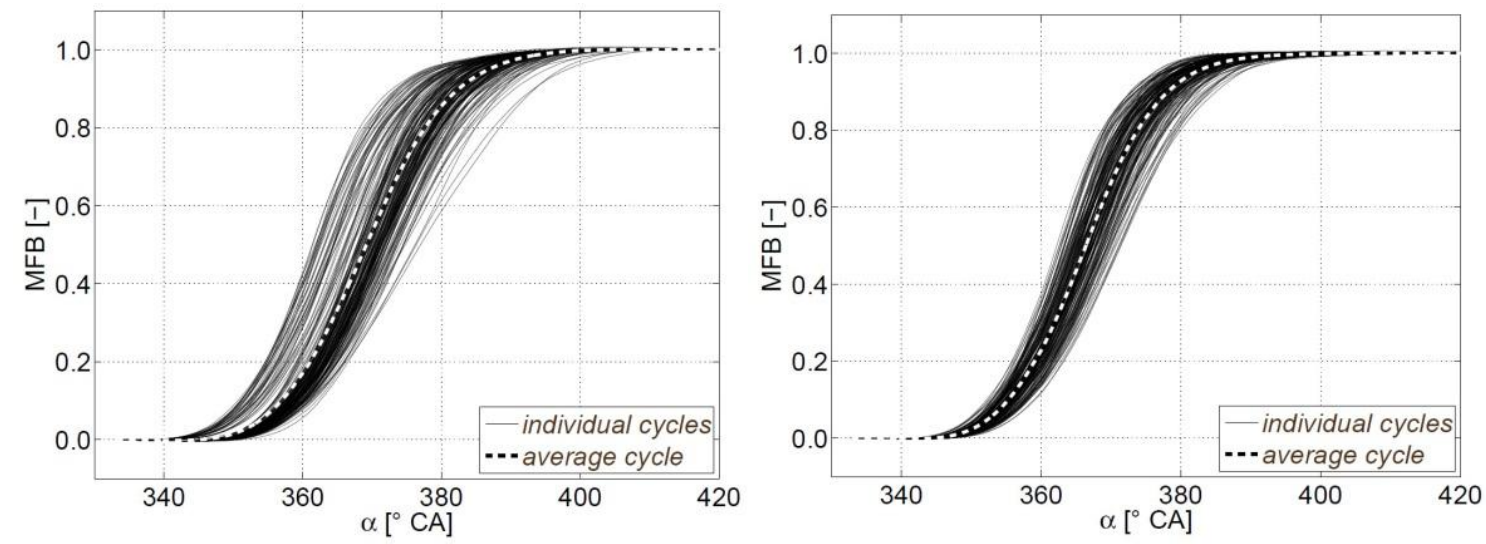

Fig. 7 Mass fraction burnt (MFB) when combusting natural (left) or synthesis (right) gas (Conditions: spark advance $\varphi_{\text {ign }}=25^{\circ} \mathrm{CA} \mathrm{BTDC}$, load $\alpha_{\text {throttle }}=100 \%$, air excess ratio $\lambda=1$, speed $\mathrm{n}=1500 \mathrm{~min}^{-1}$ )

The last picture (Fig. 8) shows the impact of the course of spark advance on the character of the burnt fuel (syngas).
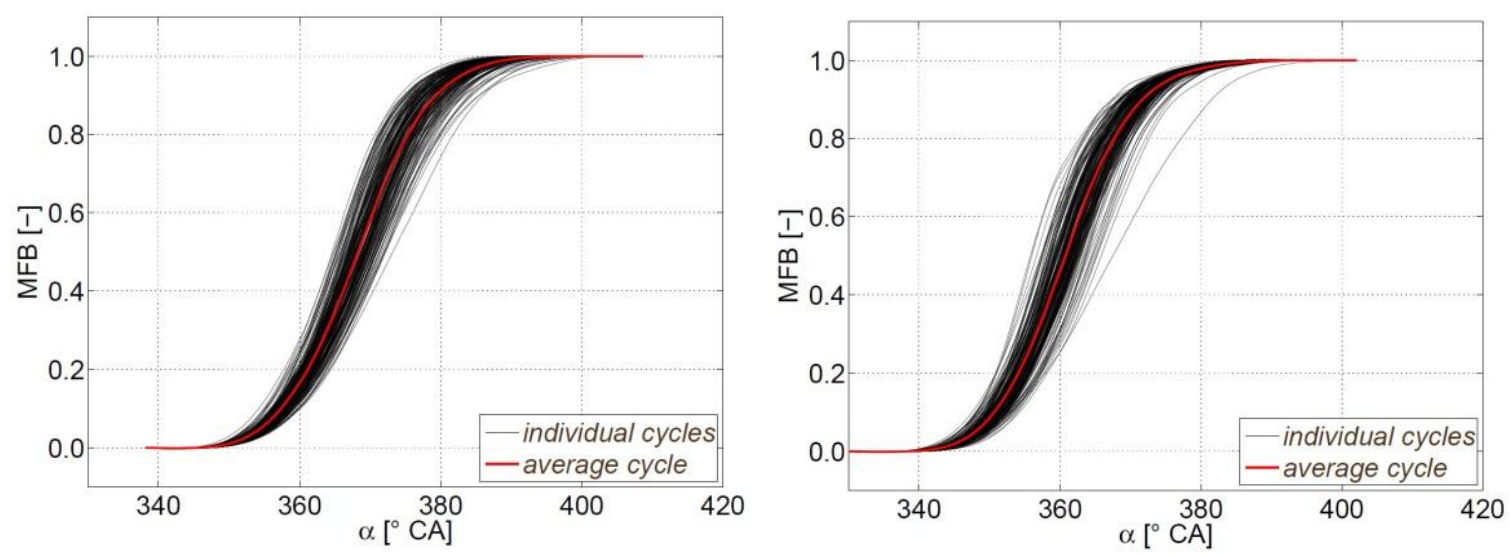

Fig. 8 Mass fraction burnt (MFB) at the angle of spark advance $\varphi_{\text {ign }}=22{ }^{\circ} \mathrm{CA}$ BTDC (left) and $\varphi_{\text {ign }}=30^{\circ} \mathrm{CA}$ BTDC (right)

(Conditions: fuel: synthesis gas SGE1, load $\alpha_{\text {throttle }}=100 \%$, air excess ratio $\lambda=1$, speed $\mathrm{n}=1500 \mathrm{~min}^{-1}$ ) 
Numeric values of the measured angles of rotation of the crankshaft, as depending on the percentage of burnt fuel, with coefficients of variation (COV), are shown in Table 3.

Tab. 3 The values of the angle of crankshaft after gradual burning 5\%, 10\%, 50\% and 90\% of fuel (MFB), and related values of the coefficient of variation (COV)

\begin{tabular}{|c|c|c|c|c|c|c|c|c|}
\hline & \multicolumn{4}{|c|}{ Synthesis Gas SGE1 } & \multicolumn{4}{c|}{ Natural Gas NG } \\
\hline & $\varphi_{\text {ign }}=22{ }^{\circ} \mathrm{CA} \mathrm{BTDC}$ & $\varphi_{\text {ign }}=30{ }^{\circ} \mathrm{CA} \mathrm{BTDC}$ & \multicolumn{2}{|c|}{$\varphi_{\text {ign }}=22{ }^{\circ} \mathrm{CA} \mathrm{BTDC}$} & \multicolumn{2}{c|}{$\varphi_{\text {ign }}=30{ }^{\circ} \mathrm{CA} \mathrm{BTDC}$} \\
\hline & $\alpha\left[{ }^{\circ} \mathrm{CA}\right]$ & $\mathrm{COV}_{\alpha}[\%]$ & $\alpha\left[{ }^{\circ} \mathrm{CA}\right]$ & $\mathrm{COV}_{\alpha}[\%]$ & $\alpha\left[{ }^{\circ} \mathrm{CA}\right]$ & $\mathrm{COV}_{\alpha}[\%]$ & $\alpha\left[{ }^{\circ} \mathrm{CA}\right]$ & $\mathrm{COV}{ }_{\alpha}[\%]$ \\
\hline $5 \%$ MFB & 354.5 & 0.27 & 348.0 & 0.32 & 355.9 & 0.30 & 349.3 & 0.36 \\
\hline $10 \%$ MFB & 357.4 & 0.30 & 350.8 & 0.36 & 359.1 & 0.34 & 352.1 & 0.38 \\
\hline $50 \%$ MFB & 368.4 & 0.46 & 360.8 & 0.51 & 371.3 & 0.53 & 362.6 & 0.53 \\
\hline $90 \%$ MFB & 379.0 & 0.61 & 371.3 & 0.50 & 383.4 & 0.79 & 373.3 & 0.63 \\
\hline
\end{tabular}

\section{CONCLUSION}

The utilization of synthesis gas in the spark-ignition engine and the impact of this fuel on the power and economic parameters, as well as on the parameters relative to the actual incineration, when compared to natural gas data, can be summarized as follows:

- the power parameters (Fig. 1) for synthesis gas from pyrolysed plastics (SGE1), compared to the natural gas data, have been reduced by about 5-6\% across the overall operating speed range, under the optimum angle of spark advance $25^{\circ} \mathrm{CA}$ BTDC set at speed $1500 \mathrm{~min}^{-1}$,

- characteristic curves of the engine torque (Fig. 3), or performance parameters of the engine, depending on the angle of spark advance, is the same both for natural and synthesis gas,

- the angle of the ignition delay in synthesis gas increases by about $5-7 \%$, compared with natural gas,

- the specific fuel consumption (Fig. 2) has increased by about $127 \%$ for synthesis gas combustion as compared to natural gas data, a rise in value from $245 \mathrm{~g} \cdot \mathrm{kW}^{-1} \cdot \mathrm{h}^{-1}$ to 578 $\mathrm{g} . \mathrm{kW}^{-1} \cdot \mathrm{h}^{-1}$ at $1500 \mathrm{~min}^{-1}$. This equals effective efficiency of the engine $30 \%$ for natural gas, and $33 \%$ for synthesis gas,

- in terms of pressure courses (Fig. 4), the synthesis gas has not significantly affected the value of maximum pressure nor pressure rise increase, compared to natural gas,

- as for combusted synthesis gas, the nature of the fuel burning is more uniform (lower $\mathrm{COV}$ ) for all successive cycles compared to the combusted natural gas (Fig.7, Tab. 3),

- synthesis gas SGE1 obtained from pyrolysis of plastics is a quality fuel fully suitable to be utilized in cogeneration units.

\section{ACKNOWLEDGMENT}

This work was supported by the Slovak Research and Development Agency under Contract-No. APVV-0015-12 and Contract-No. APVV-14-0399 and was also supported by the Scientific Grant Agency under the Contract No. VEGA 1/0017/14 and by the Ministry of Economy of the Slovak Republic via innovation voucher 2015. 


\section{REFERENCES}

[1] ARROYO J., MORENO F., MUNOZ M., MONNÉ C., BERNAL N.: Combustion behavior of a spark ignition engine fuelled with synthetic gases derived from biogas, Fuel, 2014, Volume 117, pp. 50-58,

[2] VERHELST, S., WALLNER, T.: Hydrogen-fuelled internal combustion engines, Progress in Energy and Combustion Science, 2009, Volume 35, pp. 490-527

[3] POLÓNI M., KÁlMAN P., LACH J., SMIEŠKO Š., LAZAR L., KUNC P., JANČOŠEK L.: Micro-cogeneration Unit with Variable-Speed Generator, International Scientific Event "Power Engineering 2010”, May 18-20, 2010, Tatranské Matliare, High Tatras, Slovak Republic. $9^{\text {th }}$ International Scientific Conference: Energy-Ecology-Economy (EEE) 2010, Proceedings on CD, ISBN 978-80-89402-236, Paper address: CD/files/Eee/5/4, 22 pages.

[4] CEVIZ M. A., ÖNER I. V., KAYA F., KARACALI T.: Analysis of the thermal efficiency and cyclic variations in a SI engine under lean combustion conditions, Journal of Thermal Science and Technology, 2011, pp. 121-127, ISSN: 1300-3615

[5] CHRÍBIK A., POLÓNI M., LACH J., JANČOŠEK L', KUNC P., ZBRANEK J.: Synthesis gas from pyrolysed plastics for combustion engine, Scientific proceedings 2015, Faculty of Mechanical Engineering, STU in Bratislava, ISSN 1338-1954, ISSN 1338-5011 (online version)

[6] KLEIN M.: A specific heat ratio model and compression ratio, PhD. Thesis Linkoping 2004, Division of Vehicular Systems, Linkoping University, Sweden ISSN 91-7373992-8, ISSN 0280-7971 (online version)

[7] DANIŽ M., KÁLMAN P., POLÓNI M.: Simulation of parameters of internal combustion engines, Strojnícky časopis (Journal of Mechanical Engineering), 59, 2008, č.5-6, STR. 291-304, ISSN 0039-2472

[8] YUSAF T., AL-ZUHAIR S., AL-ATABY M.: Performance of diesel engine using an emulsion of biodiesel-conventional diesel fuel, Strojnicky časopis (Journal of Mechanical Engineering), 56, 2005, č.3, STR. 137-142, ISSN 0039-2472 